\title{
Thematic-integrative-based pictorial book for improving the understanding reading skills of elementary school students
}

\author{
Ade Gunawan *, Suhardi Suhardi \\ Universitas Negeri Yogyakarta. Jalan Colombo No. 1, Karangmalang, Yogyakarta, 55281, Indonesia \\ * Corresponding Author. E-mail: adhegoen92@ gmail.com \\ Received: 24 July 2017; Revised: 7 May 2019; Accepted: 22 May 2019
}

\begin{abstract}
The study aims at composing a picture book using the thematic-integrative approach that might improve the reading comprehension skills of the Grade IV students. With regards to the conduct of the study, the initiative that has been taken is research and development (R\&D). Within this initiative, product development refers to the model that has been developed by Borg \& Gall. Then, throughout the conduct of the study, 19 students had been involved as the field subjects, and the data had been gathered by means of guided interview technique, observation, product fitness questionnaire, teacher and student response questionnaire and reading comprehension skills test. Furthermore, the product effectiveness had been tested by means of the quasi-experiment method, and the data had been analysed by using the paired sample t-test with a significant rate of 0.05 . The results of the study show that: (1) the thematicintegrative-based picture book has been fit for implementation as learning media based on the "Very Good" category that has been assigned by the media expert and the "Good" category by the material expert; and (2) the thematic-integrative-based picture book has been effective in improving the reading comprehension skills as having been confirmed by the improvement from the mean score 72.11 in the pre-test results into the mean score 81.63 in the post-test results. The improvement in the students' reading comprehension skills has been shown by the significance value (p) 0.000 . In addition, based on the paired-sample $t$-test, it is found that $\mathrm{p}<0.05$. This value indicates that the thematic-integrative-based picture book has a significant influence on the improvement of reading comprehension skills among Grade IV students.
\end{abstract}

Keywords: picture book, thematic-integrative, reading comprehension skills

How to Cite: Gunawan, A., \& Suhardi, S. (2019). Thematic-integrative-based pictorial book for improving the understanding reading skills of elementary school students. Jurnal Prima Edukasia, 7(2), 150-161. doi:https://doi.org/10.21831/jpe.v7i2.14993

doi

https://doi.org/10.21831/jpe.v7i2.14993

\section{Introduction}

Learning is an essential process within the life of any individual. It is through the learning process that an individual will attain the tools or vehicles for becoming an individual with a better personality. In other words, it might be defined that learning is a process of attaining novel knowledge, skills and even behavioural changes. The important role that learning holds requires an individual to attain the learning process and, at the same time, inherits the individual with the learning process as part of the human resources development itself.

There are so many aspects that an individual should master in his or her learning process. One of the most important and highly influential aspects in the life activities of an individual is language. Through language, an individual might establish communication from one to another, and within this communication, there will be an interaction between the message transmitter and the message retriever. Individuals will be connected and might share their information and experience from one to another as part of the learning activities. Kramina (Zascerinska, 2010) states that language learning is a conscious process and is a product of either a formal learning situation or a self-study program. In other words, it might be stated that language learning is a process that an individual consciously performs and the language learning activities might be pursued by an individual both in the formal or in the independent learning situations.

As an inseparable aspect within the context of daily life, language skills should always be 
learned and exercised. In elementary schools, the language learning or teaching activities depart from the most fundamental skills such as understanding, spelling, reading and writing letters; these fundamental skills are taught in the lower grade of elementary school. Later, as the students enter the higher grade of elementary school, the language learning or teaching activities will be wider and deeper, and the difficulty level itself will improve.

Furthermore, one of the language skills that are very important to be mastered by the students is reading skills. The mastery of reading skills is closely related to the learning activities that the students will undergo in the school and is also closely related to the daily life of the students outside the school. Nurgiyantoro (2010) emphasizes the importance of the reading skills mastery by the students since within the domain of education the reading tasks and activities are of utmost priority. Most of the science mastery for the students is attained through the reading activities.

There are several factors that might influence the reading skills mastery of the students. In the school that serves as the students' learning arena and facility, the teacher and the learning process within the classroom might be a huge influence for the success in teaching the reading skills to the students. Therefore, in order to optimize the reading skills learning process, there should be a tool that might assist and facilitate the conduct of the teacher's duty. One of the tools that might be utilized to meet this objective is learning media.

The use of learning media might be selected because learning media is relevant to the characteristics of the students, especially the ones in the elementary school grade. The elementary school students, in general, tend to favour and to be happy with the concrete and interesting learning media. The cognitive development of the elementary school students that is still in the concrete operational stage also supports the fact that the use of media in the elementary school should be concrete, practical and realistic. Flavel states that the children who belong to the concrete operational stage have the characteristics of approaching the real problems, thinking practically and always being focused to the reality in front of them (Slavin, 2014).

Media might be benefitted by the teachers to provide more authentic and interesting learning experiences for the students. A number of media nowadays have been developed, and therefore the teachers are expected to be able to utilize the media for achieving the expected learning objectives. The use of the media itself is expected to improve the students' reading skills quality in the classroom.

Nowadays, media have been much utilized as the bridge for delivering the learning materials. The reason is that the media have much assisted in the conduct of the learning process, especially for the teachers in delivering the materials to the students. Kozma (Annand, 2008) states that the capabilities of a medium can impact learning outcomes. Indeed, the learning media hold the capacity to improve the learning results. Through the use of media, the learning process will be more optimum in achieving the targeted learning objectives.

Similar to the other subjects, the learning process of Bahasa Indonesia, especially in the elementary school grade, demands media as the booster since the learning conditions of Bahasa Indonesia has been the main problem for many elementary schools. One of the elementary schools that have suffered from such a situation is State 1 Kalijajar Elementary School. The State 1 Kalijajar Elementary School has implemented the 2013 Curriculum, but the students' reading skills, especially the reading comprehension ones, have still been limited. As a result, the implementation of the new curriculum has made the teachers suffer from difficulties in maximizing the students' learning activities in the reading skills. The learning process still seems to be teacher-centred. In the same time, the limited learning sources provided by the government with their poor distribution and also the limited use of the learning media have caused several difficulties for the students' learning activities in the reading skills.

The use of media will be very helpful for the teachers because the media becomes the learning process complimentary. (Rao, 2014) explains that the media, if used in an educational setting, will complement the teaching-learning process. Similar to the learning process of reading activities, learning media will complement and assist the students' reading activities as part of improving the students' reading skills.

The media that might be utilized by the teachers in teaching reading skills consist of several forms. These forms might be printed, audio, visual or even the combination on the three of them. In the same time, the fitness into the students' characteristics also become the consideration for the teachers in selecting the sufficient media. Specific to the elementary school grade, 
the students will like something that has been related to the visual aspects because, through the visual aspects, such as pictures, for example, they will be able to grasp and imagine something.

The selection of the media that contain visual elements such as pictures is very suitable in supporting the development of the students' reading skills. Wright \& Sherman (Merc \& Kampusu, 2013) explains that visuals are commonly used to encourage and develop students' interests and competencies in reading. In relation to the statement, the picture books that contain visual aspects might be utilized as the tool for developing and improving the students' learning competencies and, specifically, reading skills. Similarly, (Gambrell \& Jawitz, 1993) also explain instructing the students to learn using the illustrated text is highly sufficient for improving the students' listening and comprehension reading skills.

Within the course of the study, the media that will be developed is a thematic-integrative picture book. The thematic-integrative picture book that will be developed is the combination of reading texts and pictures. Lewis explains that picture books have been one of the printed material that teachers might deliver to the students in order to facilitate objective learning delivery (Youngs \& Serafini, 2013). In addition, Nikolajeva \& Scott explains that picture books as books in which both pictures and texts working together is essential for telling a story (Lohfink, 2015). In other words, it might be concluded that picture books, or picture books, refer to the books that have combined the pictures and the texts in order to tell a story. Through the use of the picture books, the students will be able to be more focused in their learning activities (Mourão, 2016).

The picture book that will be developed within the study belongs to the informational picture book category. (Matulka, 2008) states that the informational picture book is essentially similar to any picture book that has been utilized in the learning process, but the informational picture book displays information more in the form of textbooks or reading materials. By reading the informational picture book, the students might learn about the world and all other aspects (Tompkins, 2002). Different than other picture books which promote illustrations or pictures more, the informational picture book displays the picture and the text under the wellbalanced proportion.

The picture book that will be developed is intended to serve as the learning media that might be utilized for improving the students' reading skills. One of the main features in the reading activities is understanding the content of the reading materials. Gambrel, Block \& Pressly (Ness, 2009) explains that the most important thing about reading is comprehension. In other words, it might be defined that the most important thing that should be achieved from the reading activities, especially in the course of the academic objectives, is understanding the content of the reading materials itself.

The importance of mastering reading comprehension skills is based on the perspective that reading comprehension becomes an important part of the occurrence of interactive communication. Paris \& Hamilton (Israel \& Duffy, 2014) explain that the comprehension toward reading materials is part of a set of knowledge that reflects the communicative interaction among the author, the message, the reader objective and the occurring interaction. Reading activities, especially reading comprehension activities, are an effective tool for improving the students' knowledge. Therefore, the learning process should be designed in such a way that the students might be drawn to attend the learning process in the reading activities within the classroom so that their knowledge might be improved.

Based on the overall elaboration, and by paying attention to the learning needs, it is deemed important that the development of thematic-integrative picture book development should be pursued to improve the reading comprehension skills for the Grade IV students. Through the development, it is expected that the students might gain more meaningful and realistic learning experience, especially for the reading skills. Besides, the use of the thematicintegrative approach within the picture book is expected to turn the learning process that the students attend to be more enjoyable yet meaningful.

\section{Method}

The nature of the study was Research and Development (R\&D). Then, the product development that had been implemented adopted the Borg \& Gall Model (Borg \& Gall, 1983, p. 774). The Borg \& Gall model itself consists of ten stages namely: (1) research and information collecting; (2) planning; (3) developing preliminary form of product; (4) performing preliminary field testing; (5) performing main product revision; (6) performing main field testing; (7) performing operational product revision; (8) 
performing operational field revision; (9) performing final product revision; and (10) disseminating and implementing the product (Fani \& Sukoco, 2019; Ghazali et al., 2019).

The testing that had been conducted within the study aimed at composing the picture book using the thematic-integrative approach and measuring the effect of the product that has been developed. Then, the product testing within the research and development initiative consisted of (1) product validation test by the experts; (2) limited-scale test; (3) expanded-scale test; and (4) operational field test.

The subjects that had been involved in the research and development initiative were assigned to the above tests. First, the subjects for the conduct of the limited-scale test were 6 Grade IV students from the State I Penaruban Elementary School. Second, the subjects for the conduct of the expanded-scale test were 15 Grade IVA students from the State I Kalijajar Elementary School. Third, the subjects for the conduct of the operational field test were 19 Grade IVB students from the State I Kalijajar Elementary School.

The data gathering techniques that had been implemented in the study were interview, observation, questionnaire and test. The interview and the observation were conducted at the beginning of the study as part of preliminary study and information collecting initiative in order to identify the problems during the conduct of the learning process. Then, the fitness assessment sheet in the form of expert judgment questionnaire aimed at assessing the fitness of the product that had been developed. The fitness assessment was performed by the learning media expert and the learning material expert. Last but not least, the reading comprehension skills test was also administered before and after the use of the picture book during the conduct of the operational field test in order to gather the data on the effectiveness of the product that had been developed.

Several data-gathering instruments had been used in the data-gathering activities during the conduct of the limited-scale test, the expanded-scale test and the operational field test. These instruments were teacher interview guideline, expert fitness assessment questionnaire, teacher response questionnaire and student response questionnaire and also reading comprehension skills test.

The data analysis technique was adjusted to the type of data that had been gathered. Despite the adjustment, the data that had been gathered by means of interview, expert assessment questionnaire, teacher and student response questionnaire and reading comprehension skills test were analysed both qualitatively and quantitatively. The qualitative data consisted of: (1) results of teacher interview; (2) feedback and suggestions from the media expert and the material expert; and (3) feedback from the teacher response and the student response. The data that had been gathered were analysed and described qualitatively as the basis of reference for the product revision.

On the other hand, the quantitative data in the study consisted of (1) the score of product fitness assessment by the experts; (2) the results of the teacher and the student response; and (3) the results of the reading comprehension skills test. The quantitative data were analysed by using the following technique: (1) tabulating the data that had been gathered; (2) calculating the total score, the total mean score and the mean score of each component; and (3) converting the mean score into the score with certain criteria. According to (Widoyoko, 2012), the scores that had been attained should be converted under the criteria that might be consulted in Table 1 .

Table 1. Conversion of Interval Score into Criteria Score

\begin{tabular}{lcc}
\hline \multicolumn{1}{c}{ Score Interval } & Score & Category \\
\hline $\mathrm{X}>\mathrm{x}_{\mathrm{i}}+1.80$ IDS & A & Very Good \\
$\mathrm{x}_{\mathrm{i}}+0.60$ IDS $<\mathrm{X} \leq \mathrm{x}_{\mathrm{i}}+1.80$ & $\mathrm{~B}$ & Good \\
IDS & & \\
$\mathrm{x}_{\mathrm{i}}-0.60$ IDS $<\mathrm{X} \leq \mathrm{x}_{\mathrm{i}}+0.60$ & $\mathrm{C}$ & Moderate \\
IDS & D & Poor \\
$\mathrm{X}_{\mathrm{i}}-1.80$ IDS $<\mathrm{X} \leq \mathrm{x}_{\mathrm{i}}-0.60$ & $\mathrm{E}$ & Very Poor \\
IDS & & \\
$\mathrm{X} \leq \mathrm{x}_{\mathrm{i}}-1.80$ IDS & \\
Note: & \\
$\mathrm{X}_{\mathrm{i}}=1 / 2($ maximum score + minimum score $)$ \\
IDS $=1 / 6$ (maximum score - minimum score $)$ \\
$\mathrm{X}=$ empirical score (score that had been attained)
\end{tabular}

Within the study, it was assigned that the minimum product fitness score had been " $B$ " with the "Good" category. Thereby, if the results of both the material expert assessment and the media expert assessment had been "B" or "Good" then the product that had been developed would have been fit for serving as learning media. Then, the criteria of the product effectiveness were attained from the results of the students' reading comprehension skills test. Then data on the improvement of the students' reading comprehension skills test before and after using the picture book were analysed using the statistical test. The statistical test that had been assigned was the 
paired sample t-test since the analysis involved two treatments on the same subjects toward one influence. The criteria for the acceptance and the rejection of $\mathrm{Ho}$ in the significance rate 5\% referred to the following principle: (1) if the significance rate was higher than $0.05(\alpha>0.05)$ then Ho had been accepted, and (2) if the significance rate was lower than $0.05(\alpha<0.05)$ then Ho had been rejected.

\section{Results and Discussions}

The development of a picture book by using the thematic-integrative approach has been conducted by implementing the Research and Development (R\&D) method. The development model has been adapted from the Borg \& Gall Model in nine stages. The details on the Research $\&$ Development results might be consulted in the following paragraphs.

The first stage is the Preliminary Stage. The Preliminary Stage begins with the conduct of the field study and the information-gathering activities as the basis for the needs analysis. Then, the objective of performing the needs analysis is to review and attain information that has been related to the conduct of the learning process and also the teacher needs and the student needs within the learning process. The preliminary study and the information-gathering activities are performed by means of library study, interview with classroom teachers and observation in the State 1 Elementary School Kalijajar. The objective of the observation is the conduct of the teaching-learning process within the classroom.

The second stage is Planning. The planning is based on the needs analysis that has been conducted. Within this stage, the activities that have been performed are learning objective formulation, learning set development and picture book design composition.

The third stage is the Preliminary Product Design and Development. In this stage, the picture book is developed based on the planning activities that have been conducted in the previous stage. After the product has been designed and developed, the fitness of the product should be tested by two experts, namely a media expert and a material expert.

The fourth stage is Limited-Scale Test. The conduct of the Limited-Scale Test has involved the Grade IV students of the State 1 Elementary School Penaruban. The data that have been attained from the Limited-Scale Test is the data from the teacher response and the student response toward the product that has been developed after the product has been utilized without any learning setting.

The fifth stage is Revision Based on the Limited-Scale Test. In this stage, revisions should be made in order to improve the picture book that has been given feedback and suggestions during the activities within the Limited-Scale Test.

The sixth stage is the Expanded-Scale Test Results. The data that have been attained from the Expanded-Scale Test is the data from the teacher response and the student response toward the product that has been developed after the product has been utilized in the learning setting.

The seventh stage is Revision Based on the Expanded-Scale Test Results. The revision is performed after the Expanded-Scale Test has been completely conducted. The objective of the revision in this stage is to improve the picture book that has been given feedback and suggestions from the Expanded-Scale Test activities.

The eight-stage is the Field Operational Test. The data that have been attained from the Field Operational Test is the data from the teacher response and the student response toward the product that has been developed after the product has been utilized in the actual learning setting. In the same time, the data that have been attained are also the data that has been retrieved from the students' reading comprehension skills test results. These data should be inputted in order to measure the effectiveness of the picture book.

The ninth stage is the Final Product Revision. The Final Product Revision is conducted after the overall stages within the product test sequence have been completed. In this stage, the already fit for the implementationpicture book has been attained since the picture book has undergone several fitness assessments and tests.

The tenth stage, or the final one, is Dissemination. The product that has been completely developed and tested should be disseminated. The Dissemination is conducted by distributing the product that has been developed on a wide scale.

\section{Results of Product Test}

The data from the product test sequence consisted of product validation data by the experts, the limited-scale test data, the expandedscale test data and the field operational test data. The data from the product assessment results 
were in the form of mean score. The mean score later was converted into the five-scale scoring criteria. The further details on the fitness assessment results of the product that had been developed might be consulted in the following paragraphs.

The overall score from the results of the assessment by the material expert is 87 , while the overall mean score from the assessment results was 3.87 with the "Good" category. The results of the analysis toward each aspect within the fitness assessment by the material experts might be consulted in Table 2.

Table 2. Results of Fitness Assessment by the Material Experts

\begin{tabular}{cccc}
\hline No. & \multicolumn{1}{c}{ Aspect } & Score & Criteria \\
\hline 1. & Picture Book Quality & 26.00 & Good \\
2. & Content Fitness & 40.00 & Good \\
3. & Language Fitness & 21.00 & Moderate \\
\hline
\end{tabular}

Based on the results of the material expert in the aspect of picture book quality, it was found that the score had been 26.00, the mean score had been 3.71 from the maximum score 35.00 , the minimum score had been 7 , the $x i=21.00$ and the Ideal Standard Deviation (ISD) $=4.67$ with the "Good" criteria. On the other hand, with regards to the aspect of content fitness by the material expert, it was found that the score had been 40.00 , the mean score had been 4.00 from the overall score 50.00 , the minimum score had been 10.00 , the $x i=30.00$ and the ISD $=6.67$ with the "Good" category. Last but not least, with regards to the aspect of language fitness by the material expert, it was found that the score had been 21.00 , the mean score had been 3.50 from the maximum score 30.00 , the minimum score had been 6.00 , the $x i=18.00$ and the overall ISD $=4.00$ with the "Moderate" category. Departing from the overall assessment results by the material expert, it was apparent that the thematic-integrative approachbased picture book had been fit from the aspect of quality, content fitness and language fitness.

On the other hand, the results of the assessment by the media expert in overall showed that the overall score had been 108.00 while the mean score had been 4.70 with the "Very Good" category. The results of the analysis on teach aspect might be consulted in Table 3 .

Based on the results of the media expert in the aspect of picture book component, it was found that the score had been 56.00, the mean score had been 4.67 from the maximum score 60.00 , the minimum score had been 12.00 , the xi $=36.00$ and the ISD $=8.00$ with the "Very Good" criteria. On the other hand, with regards to the aspect of composition principles by the media expert, it was found that the score had been 34.00 , the mean score had been 4.86 from the overall score 35.00 , the minimum score had been 7.00, the $\mathrm{xi}=21.00$ and the ISD $=4.67$ with the "Very Good" category. Last but not least, with regards to the aspect of display fitness by the media expert, it was found that the score had been 18.00, the mean score had been 4.50 from the maximum score 20.00 , the minimum score had been 6.00 , the $x i=12.00$ and the overall ISD $=2.67$ with the "Very Good" category. Departing from the overall assessment results by the media expert, it was apparent that the thematic-integrative approachbased picture book had been fit from the aspect of component, composition principle and display fitness.

Table 3. Results of Fitness Assessment by the Media Expert

\begin{tabular}{clcc}
\hline No. & \multicolumn{1}{c}{ Aspect } & Score & Criteria \\
\hline 1. & Composition & 56.00 & Very Good \\
& Component & & \\
2. & Composition Principle & 34.00 & Very Good \\
3. & Display Fitness & 18.00 & Very Good \\
\hline
\end{tabular}

The limited-scale test was conducted by involving the Grade IV students of the State 1 Elementary School Penaruban. The limited-scale test was performed in order to identify the assessment from the student perspective toward the product that had been developed. The data that had been attained from the limited-scale test were the results from the teacher response and the student response toward the product that had been developed after the product had been utilized without any learning setting. The results of the teacher response show that the overall score had been 80.00 with the mean score 4.40 , the maximum score had been 90.00 , the minimum score had been 18.00 , the $\mathrm{xi}=54.00$ and the ISD $=$ 12.00 with the "Very Good" category. The results of the analysis from each aspect might be consulted in Table 4.

Table 4. Results of Teacher Response in the Limited-Scale Test

\begin{tabular}{cccc}
\hline No. & \multicolumn{1}{c}{ Aspects } & Score & Criteria \\
\hline 1. & Language Fitness & 20.00 & Good \\
2. & Content Fitness & 26.00 & Very Good \\
3. & Display Fitness & 14.00 & Very Good \\
4. & Picture Book Quality & 20.00 & Very Good \\
\hline
\end{tabular}

Based on the results of the teacher response (Table 4), in the aspect of language fitness, it was found that the score had been 20.00 , the 
mean score had been 4.00 from the maximum score 25.00, the minimum score had been 5.00, the $x i=15.00$ and the ISD $=3.33$ with the "Good" category. Then, in the aspect of content fitness, it was found that the score had been 26.00, the mean score had been 4.33 from the maximum score 30.00 , the minimum score had been 6.00, the $\mathrm{xi}=18.00$ and the ISD 4.00 with the "Very Good" criteria. Furthermore, in the aspect of display fitness, it was found that the score had been 14.00, the mean score had been 4.67 from the maximum score 15.00 , the minimum score 3.00 , the $\mathrm{xi}=9.00$ and the ISD $=2.00$ with the "Very Good" category. Last but not least, in the aspect of quality, it was found that the score had been 20.00, the mean score had been 5.00 from the maximum score 20.00, the minimum score had been 4.00 , the $\mathrm{xi}=12.00$ and the ISD $=2.67$ with the "Very Good" category.

On the other hand, the results from the student response in overall showed that the score had been 69.50, the mean score had been 4.60, the maximum score had been 75.00, the minimum score had been 15 , the $x i=45.00$ and the ISD $=10.00$ with the "Very Good" category. The results of the analysis of each assessment aspect might be consulted in Table 5 .

Table 5. Results of Student Response in the Limited-Scale Test

\begin{tabular}{clcc}
\hline No. & \multicolumn{1}{c}{ Aspect } & Score & Criteria \\
\hline 1. & Language Fitness & 9.30 & Very Good \\
2. & Content Fitness & 9.30 & Very Good \\
3. & Display Fitness & 14.00 & Very Good \\
4. & Picture Book Quality & 23.00 & Very Good \\
5. & Reading Comprehension & 13.83 & Very Good \\
& Skills & & \\
\hline
\end{tabular}

Based on the results of the student response (Table 5), in the aspect of language fitness, it was found that the score had been 9.30, the mean score had been 4.65 from the maximum score 10.00 , the minimum score had been 2.00 , the $\mathrm{xi}=6.00$ and the ISD $=1.33$ with the "Very Good" category. Then, in the aspect of content fitness, it was found that the score had been 9.30, the mean score had been 4.65 from the maximum score 10.00 , the minimum score 2.00 , the $\mathrm{xi}=$ 6.00 and the ISD $=1.33$ with the "Very Good" category. Furthermore, in the aspect of picture book quality fitness, it was found that the score had been 23.00, the mean score had been 4.60 from the maximum score 25.00, the minimum score had been 5.00 , the $x i=15.00$ and the ISD $=$ 3.33 with the "Very Good" category. Eventually, in the aspect of reading comprehension skills relevance, it was found that the score had been 13.83 , the mean score had 4.61 from the maximum score 15.00 , the minimum score 3.00 , the $\mathrm{xi}=9.00$ and the ISD $=2.00$ with the "Very Good" criteria. Within the conduct of the limitedscale test, both for the teachers and the students, there was not any feedback nor suggestion that had been found. As a result, the product was not revised and might undergo the next test stage.

The expanded-scale test was conducted for one learning day in the Grade IV A of State 1 Elementary School Kalijajar. The data that had been attained from the conduct of the expandedscale test were the data from the teacher response and the student response toward the product that had been developed after the product had been utilized in a learning setting. The results of the expanded-scale test showed that the overall score had been 81.00 with the mean score 4.50 , the maximum score 90.00 , the minimum score 18.00 , the $x i=54.00$ and the ISD $=12.00$, all of which resulted in the "Very Good" category. The results of the analysis on each aspect might be consulted in Table 6.

Table 6. Results of Teacher Response in the Expanded-Scale Test

\begin{tabular}{clcc}
\hline No. & \multicolumn{1}{c}{ Aspect } & Score & Criteria \\
\hline 1. & Language Fitness & 23.00 & Good \\
2. & Content Fitness & 27.00 & Very Good \\
3. & Display Fitness & 13.00 & Very Good \\
4. & Picture Book Quality & 18.00 & Very Good \\
\hline
\end{tabular}

Based on the results of the teacher response (Table 6), in the aspect of language fitness, it was found that the score had been 23.00 , the mean score had been 4.60 from the maximum score 25.00, the minimum score had been 5.00, the $\mathrm{xi}=15.00$ and the ISD $=3.33$ with the "Very Good" category. Then, in the aspect of content fitness, it was found that the score had been 27.00 , the mean score had been 4.50 from the maximum score 30.00 , the minimum score had been 6.00 , the $x i=18.00$ and the ISD $=4,00$ with the "Very Good" category. Furthermore, in the aspect of display fitness it was found that the score had been 13.00, the mean score had been 4.33 from the maximum score 15.00 , the minimum score had been 3.00 , the $x i=9.00$ and the ISD $=2.00$ with the "Very Good" category. Eventually, in the aspect of picture book quality, it was found that the score had been 18.00, the mean score had been 4.50 from the maximum score 20.00 , the minimum score 4.00 , the $\mathrm{xi}=$ 12.00 and the ISD $=2.67$ with the "Very Good" category. 
On the other hand, the results of the student response from the expanded-scale test showed that the overall score had been 69.50 , the mean score had been 4.60 , the maximum score had been 75.00, the minimum score had been 15.00, the $\mathrm{xi}=45.00$ and the ISD $=10.00$ with the "Very Good" category. The results of the analysis of the assessment aspect might be consulted in Table 7 .

Table 7. Results of the Student Response in the Expanded-Scale Test

\begin{tabular}{clcc}
\hline No. & \multicolumn{1}{c}{ Aspect } & Score & Criteria \\
\hline 1. & Language Fitness & 9.20 & Good \\
2. & Content Fitness & 9.00 & Very Good \\
3. & Display Fitness & 13.33 & Very Good \\
4. & Picture Book Quality & 22.73 & Very Good \\
5. & Reading Comprehension & 14.00 & Very Good \\
\hline
\end{tabular}

Based on the results of the student response (Table 7) in the expanded-scale test, in the aspect of language fitness, it was found that the score had been 9.20, the mean score had been 4.60 from the maximum score 10.00 , the minimum score had been 2.00, the $\mathrm{xi}=6.00$ and the ISD $=1.33$ with the "Very Good" category. Then, in the aspect of content fitness, it was found that the score had been 9.00 , the mean score had been 4.50 from the maximum score 10.00 , the minimum score had been 2.00, the xi $=6.00$, the ISD $=1.33$ with the "Very Good" category. Next, in the aspect of display fitness, it was found that the score had been 13.53, the mean score had been 4.51 from the maximum score 15.00 , the minimum score had been 3.00, the $\mathrm{xi}=9.00$ and the ISD $=2.00$ with the "Very Good" category. Furthermore, in the aspect of picture book quality, it was found that the score had been 22.73, the mean score had been 4.55 from the maximum score 5.00 , the $\mathrm{xi}=15.00$ and the ISD $=3.33$ with the "Very Good" category. Eventually, in the aspect of comprehension reading skills relevance, it was found that the score had been 14.00 , the mean score had been 4.67 from the maximum score 15.00, the minimum score had been 3.00, the $\mathrm{xi}=9.00$ and the ISD $=2.00$ with the "Very Good" category. Within the conduct of the expanded-scale test, there was not any feedback nor suggestion that had been found. Automatically, the product was not revised and might proceed to the operational field test.

The operational field test was conducted for six learning days in the Grade IVB of the State 1 Elementary School Kalijajar. The data that had been attained from the test were the teacher response, the student response and the results of the students' reading comprehension skills test. The results of the teacher response show that the overall score had been 83.00 with the mean score 4.61 , the maximum score had been 90.00 , the minimum score had been 18.00 , the $x i=54.00$ and the ISD $=12.00$ with the "Very Good" category. The results of the analysis on each assessment aspect might be consulted in Table 8 .

Table 8. Results of the Teacher Response in the Operational Field Test

\begin{tabular}{clcc}
\hline No. & \multicolumn{1}{c}{ Aspect } & Score & Criteria \\
\hline 1. & Language Fitness & 23.00 & Good \\
2. & Content Fitness & 27.00 & Very Good \\
3. & Display Fitness & 13.00 & Very Good \\
4. & Picture Book Quality & 20.00 & Very Good \\
\hline
\end{tabular}

Based on the results of the teacher response (Table 8), in the aspect of language fitness, it was found that the score had been 23.00, the mean score had been 4.60 from the maximum score 25.00, the minimum score had been 5.00, the $x i=15.00$ and the ISD $=3.33$ with the "Very Good" category. Then, in the aspect of content fitness, it was found that the score had been 27.00, the mean score had been 4.50 from the maximum score 15.00 , the minimum score had been 3.00 , the $\mathrm{xi}=9.00$ and the ISD $=2.00$ with the "Very Good" category. Last but not least, in the aspect of picture book quality the score had been 20.00, the mean score had been 5.00 from the maximum score 20.00 , the minimum score had been 4.00 , the $\mathrm{xi}=12.00$ and the ISD $=2.67$ with the "Very Good" category.

On the other hand, the results of the student response showed that the overall score had been 69.26 with the mean score 4.62 , the maximum score 75.00 , the minimum score had been 15.00 , the $x i=45.00$ and the ISD $=10.00$ with the "Very Good" category. The results of the analysis on each assessment aspect might be consulted in Table 9.

Table 9. Results of Student Response in the Operational Field Test

\begin{tabular}{clcl}
\hline No. & Aspect & Score & Criteria \\
\hline 1. & Language Fitness & 9.05 & Good \\
2. & Content Fitness & 9.16 & Very Good \\
3. & Display Fitness & 13.95 & Very Good \\
4. & Picture Book Quality & 23.05 & Very Good \\
5. & Reading Comprehension & 14.05 & Very Good \\
& Skills & & \\
\hline
\end{tabular}

Based on the results of the student response (Table 9), in the aspect of language fitness, it was found that the score had been 9.05, the mean score had been 4.53 from the maximum 
sore 10.00 , the minimum score had been 2.00 , the $\mathrm{xi}=6.00$ and the ISD $=1.33$ with the "Very Good" category. Then, in the aspect of content fitness, it was found that the score had been 9.16, the mean score had been 4.58 from the maximum score 10.00 , the minimum score 2.00 , the $\mathrm{xi}=$ 6.00 and the ISD $=1.33$ with the "Very Good" category. Next, in the aspect of display fitness, it was found that the score had been 13.95, the mean score had been 4.65 from the maximum score 15.00, the minimum score had been 3.00, the $\mathrm{xi}=9.00$ and the ISD $=2.00$ with the "Very Good" category. Furthermore, in the aspect of picture book quality, it was found that the score had been 23.05, the mean score had been 4.61 from the maximum score 25.00 , the minimum score had been 5.00 , the $\mathrm{xi}=15.00$ and the ISD $=$ 3.33 with the "Very Good" category. Eventually, in the aspect of reading comprehension skills relevance, it was found that the score had been 14.05 , the mean score had been 4.68 from the maximum score 15.00 , the minimum score had been 3.00 , the $x i=9.00$ and the ISD $=2.00$ with the "Very Good" category.

\section{Results of Effectiveness Test}

The results of the effectiveness test that had been conducted toward the reading comprehension skills test in the conduct of the operational field test were utilized in order to measure the effectiveness of the product that had been developed in improving the students' reading comprehension skills. The mean score of the students' pre-test results was 72.11 , while the mean score of the students' post-test results was 81.63.

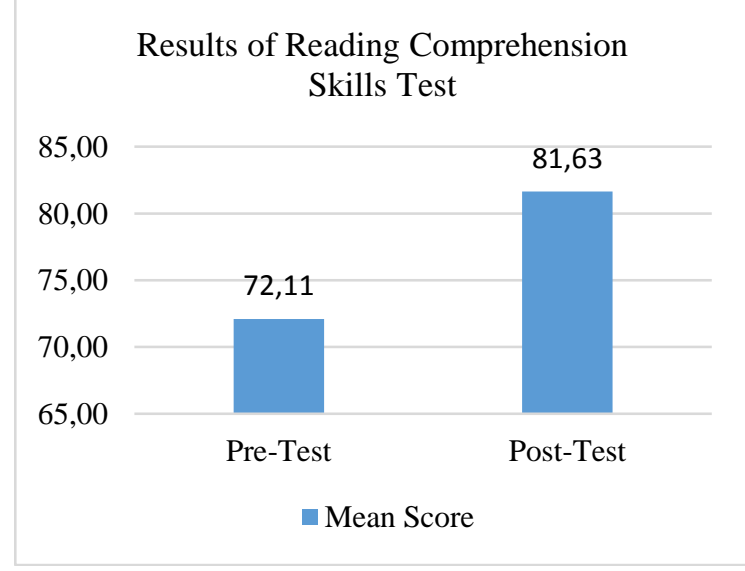

Figure 1. Diagram of the Reading Comprehension Skills Test Results

The score that had been attained should be calculated by means of the prerequisite test in order to identify whether the data distribution had been normal or not. In addition, the score that had been attained should also be calculated by means of t-test in order to identify the significance of the data. The method that had been selected for the conduct of the t-test was the paired-sample t-test.

Prior to the analysis, the results of the students' reading comprehension skills test should be calculated by means of the prerequisite test in the form of data normality test. The method that had been selected for the conduct of the prerequisite test, or the data normality test, was the Kolmogorov-Smirnov test. Then, the conduct of the normality test was based on the following hypotheses:

Ho: The data are from the normally distributedpopulation.

Ha: The data are not from the normally distributed-population.

Table 10. Results of Normality Test for the Reading Comprehension Skills

\begin{tabular}{lcc}
\hline \multicolumn{1}{c}{ Data } & Sig $(\mathrm{p})$ & Status \\
\hline Pre-Test & 0.756 & Normal \\
Post-Test & 1.002 & Normal \\
\hline
\end{tabular}

Based on the Table 10 calculation, it was found that the significance value of the pre-test data had been 0.756 while the significance value of the post-test data had been 1.002. Therefore, it might be identified that the data had been normally distributed because the significance value from both of the pre-test results and the post-test results had been higher than 0.05 ( $\mathrm{p}>$ $0.05)$. In other words, it might be concluded that the data had already met the analysis prerequisite.

Furthermore, the t-test was conducted in order to identify whether there had been improvement or not on the students' reading comprehension skills before and after the implementation of the product, namely the thematic-integrativebased picture book. The method of analysis that had been adopted in this regard was the pairedsample t-test. The paired-sample t-test calculation was performed by using the SPSS 16.00 for Windows and was based on the following hypotheses:

Ho: There is not any significant improvement in the students' reading comprehension skill after the thematic-integrative approach-based picture book has been implemented.

Ha: There is a significant improvement in the students' reading comprehension skills after the thematic-integrative approach-based picture book has been implemented. 
Jurnal Prima Edukasia, 7 (2), 2019 - 159

Ade Gunawan, Suhardi Suhardi

Table 11. Results of Normality Test for the Reading Comprehension Skills

\begin{tabular}{ccccc}
\hline \multicolumn{1}{c}{ Data } & Mean & Sig & t-count & Status \\
\hline Pre-Test & 72.11 & \multirow{2}{*}{0.000} & \multirow{2}{*}{11.752} & Significant \\
Post-Test & 81.63 & & & \\
\hline
\end{tabular}

Based on the calculation results of the paired-sample t-test, it was found that the t-count had been 11.752 and the t-table had been 1.734 with the $\mathrm{db} 19$ at the significance rate 5\%. The implication of these results was that the Ho had been rejected while the Ha had been accepted. These values showed as well that there had been significant improvement in the students' reading comprehension skills after the thematic-integrative approach-based picture book had been implemented.

\section{Discussions}

Reading skills have been one of the main skills that the students should master in their school. Through good reading skills, the students might accept numerous knowledge well. Reading activities become the vehicle for the students in attaining knowledge through the reading materials that had been delivered. (Nurgiyantoro, 2010) explains that in the domain of education reading activities and reading assignments should not be given any tolerance. Not to mention, most of the knowledge internalization within the students take place through reading activities. Therefore, it is important to improve the reading skills of the students and, in order to achieve this goal, the quality of the learning process should be improved. One of the ways for improving the quality of the learning process is using the interesting learning media that might develop the students' reading learning activities.

The presence of learning media is highly necessary for supporting the learning process. The selection and the utilization of the appropriate media will be very useful for the teachers in improving the students' reading comprehension skills. The selection of the media should pay attention to the characteristics of the students' development since the elementary school students belong to the concrete operational stage. Piaget (Ojose, 2008) explains that the students who have been 7-11 years old belong to the concrete operational stage. In this stage, the students experience enormous cognitive development in, for example, the fundamental skills and linguistic skills. The main characteristic of this stage is that the students utilize most of their sights for the learning process; consequently, the use of concrete media will be very useful, for assisting the students' learning activities.

For the elementary school students, the reading learning process will be interesting if the learning process utilizes the visual-based media or, in other words, if the learning process utilizes the picture-containing media. Wright $\&$ Sherman (Merc \& Kampusu, 2013) explains that the generally the visual media might be utilized as a good tool for developing and improving the interest and the competence of the students in the reading skills. Therefore, the selection of concrete media that contain visual elements will be the appropriate decision for the learning process and picture book becomes one of the visual and text-based learning media that might be utilized in the reading learning process.

The study that has been conducted is an effort of composing the thematic-integrative approach-based picture book that has been fit, and that might improve the students' reading comprehension skills test. The statement is based on the fact that picture book might serve as an effective reading comprehension learning media. As having been explained by Wolfenbarger \& Sipe (van den Heuvel-Panhuizen \& Elia, 2012), the use of picture book has been effective in assisting the students in developing their meaning and interpretation. The use of picture book will facilitate the students in the reading activities in order to attain the meaning and the content from the reading materials.

Based on the results of the study, it might be explained that the product that has been developed is already fit for implementation. The explanation is based on the results of the assessment by the validators, namely the material expert and the media expert. From the results of the assessment by the material expert, it is found that the total mean score has been 3.78 with the "Good" category. Therefore, departing from the assessment results, it might be concluded that the thematic-integrative approach-based picture book has already met the aspects of good fitness in terms of picture book quality, content fitness quality and language fitness quality. On the other hand, from the results of the assessment by the media expert, it is found that the total mean score has been 4.70 with the "Very Good" category. Departing from these results as well, it might be concluded that the thematic-integrative approach-based picture book has already met the aspects of display fitness, picture book component prerequisite and picture book composing elements. 
The process of conducting the field test for the thematic-integrative approach-based picture book is divided into three stages, namely the limited-scale test, the expanded-scale test and the operational field test. Based on the results of the limited-scale test, the expanded-scale test and the operational field test, it is found that the teacher response and the student response toward the utilization of the picture book have belonged to the "Very Good" category. In other words, it is clear that both of the teacher and the students have a positive response toward the thematicintegrative approach-based picture book that has been developed.

The results of the effectiveness test that have been attained from the operational field test show that the picture book has effectively improved the students' reading comprehension skills. Based on the paired-sample t-test from both the pre-test results and the post-test results of the students' reading comprehension skills test, it is found that the significance value 0.000 $<0.050$. In addition, it is also found that the tcount value has been 11.752 with the t-table value of 1.734. The attainment of the significance value (p) $<0.050$ and the t-count value $>$ the t-table value leads to the conclusion that there has been significant influence within the students' comprehension skills. The conclusion has been supported by the results, which show that the mean score of the pre-test results has been 72.11 while the mean score of the post-test results has been 81.63

Statistically, it is apparent that there has been a difference in the students' reading comprehension skills before and after the implementation of the picture book that has been developed. The results of this study have been in line with the results of the study by (Suwandi \& Masruri, 2016), which show that the students' comprehension toward the learning materials has improved after the picture book has been utilized. Similarly, the results of the study by (Budiarti \& Haryanto, 2016) show that comic has a significant influence on the improvement of the students' learning motivation and the students' reading comprehension skills in Bahasa Indonesia. In addition, the results of the study by (Indaryati \& Jailani, 2015) also show that the use of comic as learning media has been able to improve the students' learning motivation. In overall, it is apparent that the use of visual-based media has been able to stimulate and improve the students' motivation in attending to the learning process.
Departing from the findings that have been previously elaborated, it might be explained that the use of thematic-integrative approach-based picture book has been fit and effective for supporting the learning activities in the classroom. The achievement of the product fitness and the product effectiveness within the thematicintegrative approach-based picture book might not be separated from the relevance of the product to the learning needs, the students' characteristics, the learning materials, the picture book aspects and the governing curriculum. Therefore, it might be concluded that the thematic-integrative approach-based picture book that has been developed is fit and effective for the learning process within the Grade IV of Elementary School.

\section{Conclusions}

Based on the results of the study, there are several conclusions that might be drawn. First, the thematic-integrative approach-based picture book that has been developed in the study is already fit for implementation. According to the results of the assessment by the material expert, the mean score of the product is 3.78 with the "Good" category. On the other hand, the results of the assessment by the media expert, the mean score of the product is 4.70 with the "Very Good" category. Second, the thematic-integrative approach-based picture book that has been developed in the study is considered "fit" for implementation in improving the students' reading comprehension skills. The results of the paired-sample t-test show that the probability score $(\mathrm{p})<0.05$, which implies that Ho has been rejected while the $\mathrm{Ha}$ has been accepted. Therefore, it might be concluded that there has been a significant improvement in the students' reading comprehension skills after the thematicintegrative approach-based picture book has been implemented in the learning process.

\section{References}

Annand, D. (2008). Learning efficacy and costeffectiveness of print versus e-book instructional material in an introductory financial accounting course. Journal of Interactive Online Learning, 7(2), 152164.

Borg, W. R., \& Gall, M. D. (1983). Educational research: An introduction. Longman.

Budiarti, W. N., \& Haryanto, H. (2016). Pengembangan media komik untuk 
Jurnal Prima Edukasia, 7 (2), 2019 - 161

Ade Gunawan, Suhardi Suhardi

meningkatkan motivasi belajar dan keterampilan membaca pemahaman siswa kelas IV. Jurnal Prima Edukasia, 4(2), 233-242. https://doi.org/10.21831/jpe.v4i2.6295

Fani, R. A., \& Sukoco, P. (2019). Volleyball learning media using method of teaching games for understanding adobe flashbased. Psychology, Evaluation, and Technology in Educational Research, 2(1), 34. https://doi.org/10.33292/petier.v2i1.6

Gambrell, L. B., \& Jawitz, P. B. (1993). Mental imagery, text illustrations, and children's story comprehension and recall. Reading Research Quarterly, 28(3), 265-276.

Ghazali, A., Mansur, M., Widanita, N., Guntur, G., Putra, F., \& Fajaruddin, S. (2019). Developing pilates training model for decreasing the body fat ratio among overweight women. ACTIVE: Journal of Physical Education, Sport, Health and Recreation, 8(1), 9-17. https://doi.org/https://doi.org/10.15294/ac tive.v8i1.27908

Indaryati, I., \& Jailani, J. (2015). Pengembangan media komik pembelajaran matematika meningkatkan motivasi dan prestasi belajar siswa kelas V. Jurnal Prima Edukasia, 3(1), 84-96. https://doi.org/10.21831/jpe.v3i1.4067

Israel, S. E., \& Duffy, G. G. (2014). Handbook of research on reading comprehension. Routledge.

Lohfink, G. (2015). Struggling readers' "Noticings" to make meaning of picture books. The Open Communication Journal, 9(1), 12-22. https://doi.org/10.2174/1874916X015090 10012

Matulka, D. I. (2008). A picture book primer: Understanding and using picture books. Greenwood Publishing Group.

Merc, A., \& Kampusu, Y. (2013). The effect of comic strips on EFL reading comprehension. International Journal on New Trends in Education and Their Implications, 4(1), 54-64.

Mourão, S. J. (2016). Picturebooks in the primary EFL classroom. Children's Literature in Language Education Journal (CLELEjournal), 4(1), 25-43. https://run.unl.pt/handle/10362/70030
Ness, M. K. (2009). Reading comprehension strategies in secondary content area classrooms: Teacher use of and attitudes towards reading comprehension instruction. Reading Horizons, 49(2), 143-166.

Nurgiyantoro, B. (2010). Penilaian pembelajaran bahasa berbasis kompetensi. BPFE-Yogyakarta.

Ojose, B. (2008). Applying Piaget's theory of cognitive development to mathematics instruction. The Mathematics Educator, $18(1)$.

http://tme.journals.libs.uga.edu/index.php/ tme/article/view/193

Rao, B. M. (2014). Use of media as an instructional tool in English Language Teaching (ELT) at undergraduate level. International Journal of English and Literature, 5(6), 141-143.

Slavin, R. E. (2014). Educational psychology: Theory and practice. Pearson College Div.

Suwandi, I. K., \& Masruri, M. S. (2016). Pengembangan picture book sejarah nasional dengan pendekatan tematik terpadu untuk kelas IV sekolah dasar. Jurnal Prima Edukasia, 4(1), 79. https://doi.org/10.21831/jpe.v4i1.7747

Tompkins, G. E. (2002). Language arts: Content and teaching strategies. Merrill/Prentice Hall.

van den Heuvel-Panhuizen, M., \& Elia, I. (2012). Developing a framework for the evaluation of picturebooks that support kindergartners' learning of mathematics. Research in Mathematics Education, 14(1), 17-47. https://doi.org/10.1080/14794802.2012.65 7437

Widoyoko, E. P. (2012). Teknik penyusunan instrumen penelitian. Pustaka Pelajar.

Youngs, S., \& Serafini, F. (2013). Discussing Picturebooks across Perceptual, Structural and Ideological Perspectives. Journal of Language and Literacy Education, 9(1), 185-200.

Zascerinska, J. (2010). Language acquisition and language learning: eveloping the system of external and internal perspectives. 52nd International Scientific Conference. 
Available online at: http://journal.uny.ac.id/index.php/jpe

Jurnal Prima Edukasia, 7 (2), 2019, 150-161 